\title{
PERAN CITRA MEREK MEMEDIASI KEUNGGULAN PRODUK DENGAN MINAT BELI SEPEDA MOTOR YAMAHA NMAX
}

\author{
Ni Nyoman Inten Kemara Septiana Putri ${ }^{1}$ \\ I Ketut Rahyuda ${ }^{2}$
}

\author{
${ }^{1,2}$ Fakultas Ekonomi dan Bisnis Universitas Udayana, Bali, Indonesia \\ e-mail: septianainten@yahoo.com
}

\begin{abstract}
ABSTRAK
Yamaha secara tidak langsung dapat memengaruhi seseorang dalam melakukan pembelian, semakin banyak keunggulan produk serta tingginya citra merek yang dimiliki oleh sebuah produk maka akan lebih diminati oleh kebanyakan orang. Penelitian ini dilakukan di Kelurahan Kuta. Jumlah sampel yang diambil sebesar 110 sampel dengan metode purposive sampling. Teknik analisis yang digunakan adalah analisis jalur (Path analysis). Berdasarkan hasil analisis ditemukan bahwa keunggulan produk berpengaruh positif dan signifikan terhadap citra merek dan minat beli, citra merek berpengaruh positif dan signifikan terhadap minat beli, dan citra merek berperan dalam memediasi pengaruh keunggulan produk terhadap minat beli. Saran bagi perusahaan agar terus mengembangkan produk-produk yang dimiliki agar memiliki keunggulan dan dapat menciptakan citra merek bagi produk yang dihasilkan sehingga dapat membantu dalam meningkatkan penjualan.
\end{abstract}

Kata kunci: keunggulan produk, citra merek, minat beli

\begin{abstract}
Yamaha can indirectly affect a person in making purchases, the more product advantages and high brand image owned by a product will be more attractive to most people. This research was conducted in Kuta Village. The number of samples taken is 110 samples with purposive sampling method. The analysis technique used is path analysis (Path analysis). Based on the results of the analysis found that product advantages have a positive and significant effect on brand image and buying interest, brand image has a positive and significant impact on buying interest, and brand image plays a role in mediating the effect of product superiority on buying interest. Advice for the company to continue to develop products owned to have excellence and can create a brand image for the product generated so as to help in increasing sales.
\end{abstract}

Keywords: product excellence, brand image, buy interest 


\section{PENDAHULUAN}

Pada era persaingan yang begitu ketat, setiap manusia dituntut untuk dapat menerapkan efisiensi dan efektifitas dalam semua aktivitasnya, begitu pula dalam hal mobilitas dari satu tempat ketempat lain. Hal ini tentu akan berpengaruh terhadap pemilihan alat transportasi yang akan digunakan. Dari semua alat transportasi yang ada, sepeda motor menjadi transportasi favorit masyarakat karena dianggap paling efektif dan efisien (Lidya, 2016). Pilihan masyarakat ini tentu menjadi sebuah peluang besar bagi pelaku bisnis otomotif, terutama dibidang kendaraan bermotor roda dua, untuk terus menggenjot penjualannya dengan penerapan strategi pemasaran yang tepat. Inovasi yang dapat memenuhi kebutuhan dan selera konsumen mutlak diperlukan jika pelaku bisnis tidak ingin kehilangan konsumennya serta menumbuhkan permintaan akan produknya (Anggar, 2012).

Tingginya persaingan mengharuskan setiap perusahaan untuk terus mengembangkan inovasi dalam menyusun strategi dalam mempertahankan kelangsungan hidup perusahaan, memperoleh laba, memperkuat posisi perusahaan serta mengembangkan perusahaan dalam menghadapi persaingan (Khasanah, 2011).

Keunggulan suatu produk dapat membantu konsumen dalam menentukan pilihannya terhadap suatu produk, semakin berkembangnya teknologi dalam dunia otomotif saat ini menuntut perusahaan untuk selalu dapat meningkatkan keunggulan dari produk yang dihasilkan perusahaan tersebut (Tripratiwi dkk., 2016). Menurut Sunarto (2005) dalam Woran dkk. (2016) mengatakan bahwa 
produk menjadi suatu instrumen vital untuk dapat mencapai kesuksesan serta kemakmuran dalam suatu perusahaan, selain itu produk akan sukses hanya apabila perusahaan mampu menghasilkan produk yang unggul begitu pula sebaliknya perusahaan akan gagal dalam mencapai tujuan bisnisnya karena produk yang dihasilkan tidak memiliki keunggulan sehingga tidak dapat bersaing dalam pasar. Hal ini sesuai dengan penelitian yang dilakukan oleh Krisna (2013) yang menyatakan bahwa keunggulan produk menunjukkan efek yang positif dan signifikan, dimana keunggulan produk dapat memengaruhi citra merek suatu produk sehingga semakin unggul suatu produk maka citra dari sebuah merek juga akan semakin tinggi.

Keunggulan produk juga dapat memengaruhi minat beli seseorang, hal ini didukung oleh penelitian yang dilakukan oleh Tripratiwi dkk. (2016) yang menyatakan bahwa keunggulan produk akan tercapai melalui kualitas produk yang dimiliki oleh produk tersebut sehingga keunggulan produk akan terbentuk dan mempunyai pengaruh yang positif serta signifikan dalam memengaruhi konsumen untuk melakukan pembelian.

Penelitian serupa juga dilakukan oleh (Voss dan Voss, 2000 dalam Krisna, 2013) dan Sylvia (2003), Kualitas produk dibangun terlebih dulu untuk mencapai keunggulan produk, dan digunakan sebagai alat dalam meningkatkan keunggulan suatu produk serta dapat memengaruhi minat konsumen untuk membeli. Penelitian ini memperoleh hasil bahwa keunggulan produk berpengaruh negatif terhadap minat beli. Hal ini disebabkan apabila perusahaan ingin meningkatkan 
minat beli masyarakat terhadap produk yang dihasilkan, maka produk haruslah memiliki kualitas untuk dapat menonjolkan keunggulan dari produk yang dimiliki.

Suatu kreativitas dalam pengembangan suatu produk dapat dilakukan berdasarkan dari adanya permintaan pasar atau juga bisa disesuaikan dengan adanya perkembangan tekonologi. Hal ini berguna agar konsumen tidak merasa jenuh terhadap produk sehingga memiliki minat untuk mencari alternatif lain yang sesuai dengan harapan dan keinginan mereka (Komaryatin dan Ella, 2006)

Perusahaan mempunyai konsep untuk selalu menanamkan produknya di benak konsumen Arslan (2014) : Luong dkk. (2017). Perusahaan yang mempunyai citra yang baik akan mempunyai dampak yang menguntungkan, sedangkan citra yang buruk akan merugikan organisasi Sutisna (dalam Surya Ningrum, 2014). Merek kuat yang dimiliki oleh perusahaan dapat meningkatkan kepercayaan konsumen dalam menggunakan produk atau jasa yang dibeli (Jalilvand 2012). Citra merek juga sering dijadikan sebagai isyarat ekstrinsik ketika konsumen mengevaluasi produk sebelum memutuskan untuk membeli (Dick dan Jain, 1994 dalam Wang, 2014).

Belakangan perkembangan bisnis di Indonesia menunjukkan keberhasilannya yang pesat dalam meraih laba serta menanamkan citra merek dalam benak konsumen.Semakin besarnya keberhasilan suatu citra merek yang tertanam dalam benak konsumen, menjadikan konsumen tersebut loyal atas suatu produk atau jasa yang disediakan oleh perusahaan atau pemasar (Nany, 2006). Hal ini berdampak positif terhadap laba yang didapatkan perusahaan yang memiliki citra merek terhadap produk tersebut. 
Konsumen yang merasakan kepuasan akan suatu citra merek terhadap produk pilihannya memberikan pengaruh dalam benak konsumen untuk terus melakukan pembelian terhadap suatu produk atau jasa tersebut. Produk yang memiliki merek akan menjadikan produk tersebut lebih menarik dan unik dan juga akan menjadi ciri khas dari produk tersebut yang dapat membedakannya dengan produk pesaing. (Fitriana dan Yulianti, 2014)

Sebuah produk tentu memiliki citranya masing-masing didalam benak konsumen, ini disebabkan karena merek merupakan sebuah identitas yang dapat membedakan suatu produk atau jasa dari perusahaan. Citra merek yang dikomunikasikan dengan baik akan dapat digunakan untuk membantu membangun posisi merek. Pada akhirnya citra merek menjadi hal penting dalam memengaruhi konsumen menentukan pilihan untuk membeli atau tidak. (Bian dan Moutinho, 2011).

Perkembangan industri sepeda motor di Indonesia sangatlah menjanjikan. Hal ini dapat dilihat dari perkembangan jumlah kendaraan bermotor tahun 2016, jumlah sepeda motor mendominasi dan mencapai lebih dari 100 juta unit (www.bps.go.id). Simbolon (2013) mengungkapkan bahwa konsumen sekarang ini sedikit sulit menentukan pilihan terhadap sepeda motor yang akan dibeli dikarenakan banyaknya pilihan yang ada dari berbagai merek.

PT. Yamaha Motor adalah salah satu perusahaan otomotif yang memiliki kontribusi cukup besar dalam penyediaan alat transportasi kendaraan roda dua dengan kualitas tinggi dan penjualan yang tersebar di seluruh Indonesia. Total jaringan Yamaha di Indonesia tidak kurang dari 3000 dealer dan bengkel. Inovasi 
Ni Nyoman Inten Kemara Septiana Putri, Peran Citra Merek...

dilakukan Yamaha dari segi proses produksi maupun pelayanan yang selalu berorientasi terhadap keinginan dan kepuasan pelanggan serta komunitas sebagai prioritas utama perusahaan (www.yamaha.com).

Persaingan dunia otomotif yang begitu pesat terutama di tipe motor matic dengan berbagai tipe dari berbagai produsen otomotif besar membuat Yamaha tidak ingin kalah bersaing dengan para pesaingnya yang kini mampu untuk menguasai pasar. Yamaha tidak tinggal diam dengan dominasi yang dilakukan oleh para pesaing nya, hal ini menyebabkan Yamaha segera meluncurkan produk skuter matic terbarunya yang diberi nama Yamaha NMax dengan kelas $155 \mathrm{cc}$.

Yamaha NMax ini diluncurkan pada bulan Januari 2015 lalu. Yamaha NMax merupakan produk global keduayang dimiliki oleh Yamaha setelah Yamaha Majesty. NMax memiliki harga jauh dibawah pesaingnya yang memiliki type skuter matic yang sama. Yamaha NMax membawa teknologi baru yang memang disematkan untuk pasar Indonesia seperti Blue Core, Fuel Injection, Anti-lock Brake System (ABS), dan Variabel Valve Actuation. Dengan teknologi yang dibawanya NMax dapat dikatakan sebagai skuter matic kelas 155 cc yang bernuansa sporty. Teknologi LED yang diusung untuk headlamp merupakan suatu apresiasi yang diberikan oleh Yamaha dalam hal untuk menghemat energi dan pencahayaan yang diberikan juga maksimal baik itu pada malam hari maupun pada siang hari (www.yamaha.com).

Full digital juga menjadi tampilan pada speedometer Yamaha NMax yang membuat tampilan menjadi lebih modern dan informative bagi pengendaranya karena dilengkapi dengan multi information digital (MID). Hal ini merupakan 
kelengkapan speedometer pada Yamaha NMax yang juga menjadi salah satu keunggulan dari produk yang dikeluarkan oleh Yamaha. Meskipun demikian, hal ini tidak menyebabkan harga NMax melambung tinggi (www.semisena.com).

Yamaha NMax merupakan salah satu motor Yamaha yang paling diburu konsumen sepanjang tahun 2016 dalam data penjualan domestic AISI ( Asosisasi Industri Sepedamotor Indonesia). Penjualan Yamaha NMax di Indonesia sendiri berhasil menembus angka 254.826 unit. Area penjualan terbesar Yamaha NMax periode Januari - Desember 2016 menurut AISI tersebar di Jakarta yang menduduki posisi pertama dalam penjualan Yamaha NMax sebesar 84.245 unit, disusul oleh Jawa Barat yang berhasil menjual sebesar 43.030 unit, Jawa Timur menjual sebanyak 30.243 unit, Bali sebanyak 22.334 unit dan terakhir Jawa Tengah sebesar 21.288 unit ( www.motoengine.com).

Masyarakat memiliki persepsi bahwa Yamaha NMax memiliki desain, fasilitas pendukung dan fitur tambahan yang diberikan memang menjadi keunggulan produk sepeda motor Yamaha NMax dan membedakannya dengan sepeda motor merek pesaing. Produk keluaran Yamaha tidak dapat dipandang sebelah mata, Yamaha memiliki produk-produk andalan yang dapat membuat para pelanggannya merasa lebih percaya diri dan dapat meningkatkan gaya hidup pemakainya.

Citra merek yang dimiliki oleh Yamaha membuat produk-produk sepeda motor ini sangat mudah dikenali baik itu dari segi desain maupun lambang (logo). Keunggulan produk dan citra merek yang dimiliki oleh Yamaha secara tidak langsung memang dapat memengaruhi seseorang dalam melakukan pembelian, 
semakin banyak keunggulan produk serta tingginya citra merek yang dimiliki oleh sebuah produk maka produk tersebut akan menjadi lebih diminati oleh kebanyakan orang. Dapat disimpulkan bahwa citra merek dan keunggulan produk memang dapat memengaruhi seseorang dalam melakukan pembelian.

Kuta-Badung merupakan wilayah dengan kepadatan penduduk yang tinggi serta merupakan wilayah pariwisata, hal ini menyebabkan jalanan di Kuta sering tidak lepas dari kemacetan. Masyarakat di Kelurahan Kuta memilih kendaraan sepeda motor sebagai transportasi favoritnya karena dapat menghemat waktu dalam mencapai tempat yang dituju. Pemilihan merek sepeda motor pun tidak lepas dari perhatian masyarakat, sepeda motor dengan spesifikasi yang canggih serta dapat meningkatkan gaya hidup penggunanya masih menjadi pilihan masyarakat. Yamaha kembali hadir dengan mengeluarkan sepeda motor dikelas 155 cc yang diberi nama Yamaha NMax dengan sentuhan teknologi serta desain yang dapat dikatakan up to date diharapkan mampu dalam menarik minat beli masyarakat di Kelurahan Kuta terhadap sepeda motor Yamaha ini. Yamaha juga memiliki tiga dealer resmi yang berada di tempat-tempat strategis di wilayah Kuta, sehingga dapat memudahkan masyarakat dalam melakukan pembelian. Hal ini menjadi latar belakang dalam penulisan penelitian ini. Dalam penulisan ini akan diteliti mengenai pengaruh citra merek dalam memengaruhi minat konsumen dalam membeli sepeda motor NMax merek Yamaha.

Posisi keunggulan produk dipandang dari sisi fungsional maupun harga yang dalam usahanya diharapkan menjadi pemenuh harapan seorang pelanggan dengan didukung oleh atribut-atribut fisik yang melekat pada produk tersebut. 
Studi empiris dilakukan oleh Navarone (2003) menyatakan bahwa keunggulan produk merupakan suatu hal yang mutlak sehingga harus dipertahankan oleh perusahaan. Atribut produk yang melengkapi suatu merek yang sesuai dengan manfaatnya, keunikan dan juga kelebihan yang berbeda dari perusahaan lain serta memiliki tingkat efisiensi produk merupakan kunci dari peningkatan kesuksesan sebuah produk serta tentu dapat juga mengangkat citra merek dari sebuah produk tersebut.

Penelitian lainnya juga dilakukan oleh Krisna (2013), yang mendapatkan hasil bahwa keunggulan produk berpengaruh positif signifikan terhadap citra suatu merek serta semakin unggul suatu produk maka citra dari sebuah produk akan ikut meningkat di mata konsumen maupun di mata calon konsumen. Berdasarkan hasil kajian empiris yang ada dapat dibangun hipotesis sebagai berikut :

$\mathrm{H}_{1}$ : Keunggulan produk berpengaruh secara positif dan signifikan terhadap citra merek

Keunggulan produk merupakan sebuah persepsi nilai lebih atas sebuah produk dimana keunggulan produk ini akan dapat membantu perusahaan dalam meningkatkan minat beli konsumen atas produk yang ditawarkan oleh perusahaan.

Studi empiris dilakukan oleh Krisna (2013) dan Tripratiwi dkk. (2016) yang melakukan penelitian pengaruh keunggulan produk terhadap minat beli konsumen dengan hasil penelitian bahwa keunggulan produk mempunyai pengaruh yang positif dan signifikan karena dengan meningkatnya keunggulan maka citra dari sebuah merek juga akan tinggi sehingga akan memengaruhi minat seseorang untuk melakukan pembelian. 
Ni Nyoman Inten Kemara Septiana Putri, Peran Citra Merek...

Penelitian serupa juga dilakukan oleh Voss dan Voss, 2000 dalam Krisna, 2013 dan Sylvia (2003) yang menyatakan bahwa apabila suatu perusahaan ingin meningkatkan keunggulan dari sebuah produk, maka hal pertama yang harus dilakukan adalah dengan membangun kualitas dari suatu produk dan dapat dibuat sesuai dengan dimensi dari kualitas produk yang dijelaskan oleh Garvin (1998) dalam Istijanto (2007), maka dapat dikatakan hal ini akan dapat memengaruhi minat konsumen untuk membeli. Sehingga kesimpulan dari penelitian yang dilakukan oleh Sylvia memperoleh hasil bahwa keunggulan produk berpengaruh negatif terhadap minat beli.

$\mathrm{H}_{2}$ : Keunggulan produk berpengaruh secara positif dan signifikan terhadap minat beli.

Citra dibentuk oleh perusahaan untuk menguatkan keberadaan produk tersebut dan agar lebih mudah diingat dan dikenal oleh konsumen. Citra yang baik dari sebuah produk tentu akan membantu dalam peningkatan volume penjualan karena konsumen sudah mengenal dan mengetahui tentang keberadaan produk tersebut.

Studi empiris dilakukan oleh Pujadi (2010): Arista (2011): Subiyanto (2013): Norman (2014) dan Tripratiwi dkk. (2016) yang melakukan penelitian tentang pengaruh citra merek terhadap minat beli konsumen yang menunjukkan hasil bahwa citra merek berpengaruh positif signifikan terhadap minat beli. Penelitian lain juga dilakukan oleh Wang dan Tsai (2014) yang menunjukkan hasil bahwa citra merek memang dapat meningkatkan minat beli suatu produk. Berdasarkan hasil kajian empiris yang ada dapat dibangun hipotesis sebagai berikut : 
$\mathrm{H}_{3}$ : Citra merek berpengaruh secara positif dan signifikan terhadap minat beli.

Secara tidak langsung, keunggulan produk akan dapat memengaruhi minat konsumen dalam membeli suatu produk. Semakin tinggi keunggulan produk suatu produk makan dapat memengaruhi citra merek produk tersebut sehingga dapat membantu dalam memengaruhi konsumen sehingga mempunyai minat beli terhadap produk yang ditawarkan.

Penelitian ini selaras dengan penelitian yag dilakukan oleh Alim (2010), dimana hasil dari penelitiannya menyatakan bahwa citra merek yang kuat, secara tidak langsung dapat memengaruhi konsumen dalam tindakan pembelian. Penelitian serupa juga dilakukan oleh Norman (2014) yang menyatakan bahwa merek merupakan sebuah pertimbangan yang ada di pikiran konsumen sebelum membeli suatu produk,.konsumen cenderung akan memilih produk yang memiliki citra baik atau positif sehingga akan meningkatkan minat konsumen untuk melakukan pembelian, sehingga dapat dikatakan bahwa terdapat sebuah hubungan yang positif antara citra merekterhadap minat beli. Berdasarkan hasil kajian empiris yang ada dapat dibangun hipotesis sebagai berikut :

$\mathrm{H}_{4}$ : Citra merek memediasi keunggulan produk terhadap minat beli.

\section{METODE PENELITIAN}

Penelitian ini ialah penelitian asosiatif kausal (sebab-akibat) yang bertujuan untuk mengetahui apakah variabel keunggulan produk dan citra merek merupakan sebab dari terjadinya minat beli. Artinya, diduga bahwa jika keunggulan produk dan citra merek Yamaha NMax tinggi, maka mengakibatkan minat beli untuk produk tersebut juga akan semakin tinggi. 
Ni Nyoman Inten Kemara Septiana Putri, Peran Citra Merek...

Lokasi penelitian dilakukan di Kelurahan Kuta dengan menyasar masyarakat lokal daerah tersebutyang belum pernah melakukan pembelian sepeda motor Yamaha NMax. Sedangkan objek penelitiannya adalah minat pembelian sepeda motor Yamaha NMax yang ditinjau berdasarkan keunggulan produk dan citra merek.

Pada penelitian ini, variabel penelitian dan indikator variabel penelitian disajikan pada Tabel 1.

Tabel 1.

Variabel dan Indikator

\begin{tabular}{clc}
\hline Variabel & \multicolumn{1}{c}{ Indikator } & \multicolumn{1}{c}{ Sumber } \\
\hline Keunggulan Produk & Keunggulan desain $\left(\mathrm{X}_{1}\right)$ & Komaryatin \\
$(\mathrm{X})$ & Keunggulan fasilitas Produk $\left(\mathrm{X}_{2}\right)$ & dan Fauziah $(2006)$ \\
& Keunggulan fitur $\left(\mathrm{X}_{3}\right)$ & \\
& Memiliki image positif $\left(\mathrm{M}_{1}\right)$ & Astuti \\
Citra Merek & Memiliki ciri khas $\left(\mathrm{M}_{2}\right)$ & $(2011)$ dan \\
$(\mathrm{M})$ & Merek dikenal luas $\left(\mathrm{M}_{3}\right)$ & Andrianto $(2013)$ \\
& Mengikuti perkembangan jaman $\left(\mathrm{M}_{4}\right)$ & \\
& Ingin mengetahui produk lebih dalam $\left(\mathrm{Y}_{1}\right)$ & Calvin dan Samuel \\
Minat Beli & Tertarik untuk mencoba $\left(\mathrm{Y}_{2}\right)$ & (2014) \\
$(\mathrm{Y})$ & Mempertimbangkan untuk membeli $\left(\mathrm{Y}_{3}\right)$ & \\
& Ingin membeli produk $\left(\mathrm{Y}_{4}\right)$ & \\
\hline Sumber: Data diolah, 2017 & &
\end{tabular}

Pada Tabel 1 dilakukan pengklasifikasian variabel-variabel penelitian yaitu keunggulan produk, citra merek, dan minat beli. Keunggulan produk merupakan salah satu faktor yang menjadi penentu dari kesuksesan suatu produk. Indikator keunggulan produk pada penelitian ini diadopsi dari penelitian Komaryatin dan Fauziah (2006) diukur atas: keunggulan desain, keunggulan fasilitas produk, dan keunggulan fitur. Citra merek merupakan sekumpulan dari keyakinan konsumen mengenai merek tertentu. Indikator citra merek pada penelitian ini diadopsi dari penelitian Arista dan Astuti (2011) dan Andrianto (2013), diukur atas: memiliki 
image positif, memiliki ciri khas, merek dikenal luas, dan mengikuti perkembangan jaman. Minat beli muncul sebagai respon terhadap objek yang dapat menunjukkan keinginan konsumen untuk melakukan pembelian (Calvin dan Samuel, 2014). Indikator minat beli menurut Calvin dan Samuel, 2014 diukur atas: ingin mengetahui produk lebih dalam, tertarik untuk mencoba, mempertimbangkan untuk membeli, dan ingin membeli produk.

Jenis data yang digunakan dalam penelitian ini adalah data kualitatif berupa gambaran umum tentang total penjualan sepeda motor Yamaha NMax dan penilaian responden terhadap pernyataan-pernyataan yang diajukan dalam kuesioner. Data kuantitatif berupa data jumlah sampel pelanggan dan skor dari jawaban kuesioner. Sedangkan sumber data yang digunakan dalam penelitian ini adalah data primer berupa hasil jawaban kuesioner dan wawancara mengenai pengaruh citra merek, memediasi keunggulan produk terhadap minat beli. Data sekunder berupa data penjualan sepeda motor Yamaha NMax.

Populasi dalam penelitian ini adalah masyarakat yang berdomisili di Kelurahan Kuta. Pengumpulan sampel menggunakan teknik purposive sampling. Berdasarkan kiteria dan jumlah indikator yang digunakan dari penelitian dikalikan 10 maka memperoleh hasil sebagai berikut : 11 indikator x $10=110$ responden. Maka, responden yang dibutuhkan dalam penelitian ini adalah 110 responden.

Metode pengumpulan data yang digunakana dalam penelitian ini adalah kuesioner, karena kuesioner merupakan teknik pengumpulan data dengan menggunakan daftar tertulis dimana hal ini berisi seperangkat pertanyaan yang bersifat tertutup maupun terbuka yang diserahkan secara langsung kepada 
responden untuk dijawab (Rahyuda, dkk. 2016). Variabel di dalam kuesioner ini menggunakan skala likert, yaitu dengan menjabarkan variabel yang akan diukur menjadi indikator variabel. Sewaktu menanggapi pertanyaan dalam skala likert, responden menentukan tingkat persetujuan mereka terhadap suatu pernyataan dengan memilih salah satu dari pilihan yang tersedia.

Skala Likert yang digunakan dalam penelitian ini adalah skala Likert $1-5$ dengan ketentuan Skor 5 untuk jawaban Sangat Setuju (SS), Skor 4 untuk jawaban Setuju (S), Skor 3 untuk jawaban Cukup Setuju (CS), Skor 2 untuk jawaban Tidak Setuju (TS), dan Skor 1 untuk jawaban Sangat Tidak Setuju (STS)

Penelitian ini menggukanan teknik analisis jalur (path analysis). Namun sebelum melakukan uji analisis jalur, terlebih dahulu peneliti melakukan uji asumsi klasik yang terdiri dari uji normalitas, uji multikolinearitas, dan uji heteroskedastisitas.

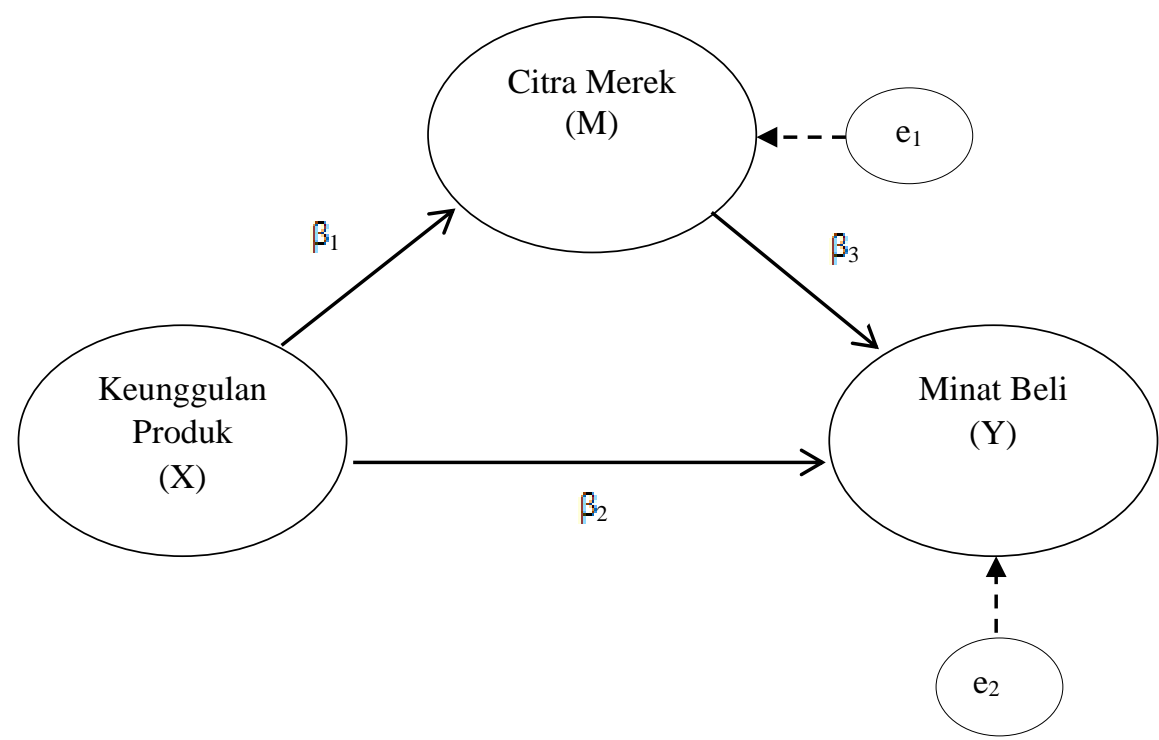

Gambar 1. Kerangka Konseptual Penelitian

Sumber: Hasil pengolahan data penelitian, 2017 
Pengaruh keunggulan produk (X) terhadap citra merek (M) ditunjukkan oleh koefisien jalur $\beta 1$, pengaruh langsung keunggulan produk $(\mathrm{X})$ terhadap minat beli (Y) diperlihatkan oleh koefisien jalur $\beta 2$, dan pengaruh citra merek (M) terhadap minat beli (Y) diperlihatkan oleh koefisien jalur $\beta 3$. Pengaruh tidak langsung keunggulan produk $(\mathrm{X})$ terhadap minat beli $(\mathrm{Y})$ diperoleh dengan mengalikan $\beta 1$ dan $\beta 2$.

Koefisien jalur dapat diperoleh dengan dua persamaan struktural, yaitu persamaan regresi yang menunjukkan hubungan yang telah dihipotesiskan. Dua persamaan struktural tersebut ialah:

$$
\begin{aligned}
& \mathrm{M}=\beta_{1} \mathrm{X}+\mathrm{e}_{1} \ldots \ldots \ldots \\
& \mathrm{Y}=\beta_{2} \mathrm{X}+\beta_{3} \mathrm{M}+\mathrm{e}_{2}
\end{aligned}
$$

Keterangan:

$\mathrm{X} \quad=$ variabel eksogen keunggulan produk

$\mathrm{M} \quad=$ variabel intervening citra merek

$\mathrm{Y} \quad=$ variabel endogen minat beli

$\beta_{1} \quad=$ koefisien jalur dari keunggulan produk ke citra merek

$\beta_{2} \quad=$ koefisien jalur dari keunggulan ke minat beli

$\beta_{3} \quad=$ koefisien jalur dari citra merek ke minat beli

$\mathrm{e}_{1}, \mathrm{e}_{2}=$ nilai standar error

\section{Uji Mediasi (Uji Sobel)}

Pengujian hipotesis mediasi dilakukan menggunakan prosedur yang dikembangkan Sobel (1982) yang disebut sebagai Uji Sobel. Uji Sobel adalah perangkat uji yang digunakan untuk mengetahui signifikansi hubungan tidak langsung variabel variabel keunggulan produk $(\mathrm{X})$ terhadap minat beli (Y) melalui varibel citra merek (M). Persamaan Uji Sobel dapat dijabarkan sebagai berikut:

$$
\mathrm{Z}=\frac{a b}{\sqrt{b^{2} s a^{2}+a^{2} s b^{2}+s a^{2} s b^{2}}}
$$


Keterangan:

$\mathrm{a}=$ koefisien regresi dari variabel bebas $(\mathrm{X})$ terhadap variabel mediasi $(\mathrm{M})$

$\mathrm{Sa}=$ standar error dari a

$\mathrm{b}=$ koefisien regresi dari variabel mediasi $(\mathrm{M})$ terhadap variabel terikat $(\mathrm{Y})$

$\mathrm{Sb}=$ standar error dari $\mathrm{b}$

Apabila hasil nilai perhitungan Z > 1,96 (tingkat kepercayaan 95 persen), maka variabel intervening dianggap secara signifikan memediasi hubungan antara variabel eksogen dan variabel endogen.

\section{HASIL DAN PEMBAHASAN}

\section{Karakteristik Responden}

Responden pada penelitian ini mengambil sampel sebesar 110 orang, karakteristik dari responden ini diukur berdasarkan jenis kelamin, usia dan pekerjaan. Berdasarkan hal tersebut maka didapatkan hasil sebagai berikut:

Tabel 2.

Karakteristik Responden

\begin{tabular}{|c|c|c|c|}
\hline No & Variabel & Klasifikasi & Jumlah (orang) \\
\hline \multirow{3}{*}{1.} & \multirow{2}{*}{ Jenis Kelamin } & Laki-Laki & 98 \\
\hline & & Perempuan & 12 \\
\hline & Jumlah & & 110 \\
\hline \multirow{5}{*}{2.} & \multirow{4}{*}{ Usia } & $22-26$ tahun & 43 \\
\hline & & $27-31$ tahun & 29 \\
\hline & & $32-36$ tahun & 31 \\
\hline & & $>37$ tahun & 7 \\
\hline & Jumlah & & 110 \\
\hline \multirow{6}{*}{3.} & \multirow{5}{*}{ Pekerjaan } & Pelajar / Mahasiswa & 23 \\
\hline & & Wiraswasta & 45 \\
\hline & & PNS / BUMN & 5 \\
\hline & & Pegawai Swasta & 20 \\
\hline & & Lainnya & 17 \\
\hline & Jumlah & & 110 \\
\hline \multirow{6}{*}{4.} & \multirow{5}{*}{ Pendapatan } & Rp 2.000.000 - Rp 3.000.000 & 25 \\
\hline & & $>\operatorname{Rp} 3.000 .000-\operatorname{Rp} 4.000 .000$ & 46 \\
\hline & & $>\operatorname{Rp} 4.000 .000-\operatorname{Rp} 5.000 .000$ & 10 \\
\hline & & $>\operatorname{Rp} 5.000 .000-\operatorname{Rp} 6.000 .000$ & 20 \\
\hline & & $>\operatorname{Rp} 6.000 .000$ & 9 \\
\hline & Jumlah & & 110 \\
\hline
\end{tabular}

Sumber : Data primer, 2017 
Tabel 2 menunjukkan bahwa responden jenis kelamin laki-laki lebih mendominasi pada penelitian ini dibandingkan dengan perempuan, dan dilihat dari segi usia, responden dengan rentan usia $22-26$ tahun lebih mendominasi, jika dilihat dari segi pekerjaan, responden yang bekerja sebagai wiraswasta lebih mendominasi dibandingkan dengan pekerjaan lainnya, sedangkan jika dilihat dari pendapatan nya pendapata antara >Rp 3.000.000 - Rp 4.000.000 merupakam pendapatan terbanyak.

\section{Hasil Uji Validitas}

Uji validitas digunakan sebagai penguji dalam menentukan sejauh mana instrumen yang digunakan dalam penelitian ini mampu mengukur variabel yang telah di tetapkan oleh peneliti. Suatu instrumen yang valid ditunjukkan dengan $\mathrm{r}$ Pearson Correlation skor total $\geq 0,30$ seperti yang disajikan pada Tabel 3 .

Tabel 3.

Uji Validitas

\begin{tabular}{ccccc}
\hline No. & Variabel & Instrumen & Pearson Correlation & Keterangan \\
\hline \multirow{4}{*}{ 1. } & \multirow{3}{*}{ Keunggulan Produk(X) } & X.1 & 0,916 & Valid \\
& & X.2 & 0,874 & Valid \\
& & X.3 & 0,859 & Valid \\
& & M.1 & 0,843 & Valid \\
3. & \multirow{2}{*}{ Citra Merek (M) } & M.2 & 0,834 & Valid \\
& & M.3 & 0,874 & Valid \\
& & M.4 & 0,883 & Valid \\
& & & & \\
& & Y.1 & 0,940 & Valid \\
4. & Minat Beli (Y) & Y.2 & 0,855 & Valid \\
& & Y.4 & 0,914 & Valid \\
& & & 0,899 & Valid
\end{tabular}

Sumber: Data primer diolah, 2017

Tabel 3 menjelaskan bahwa seluruh instrumen variabel penelitian berupa Keunggulan Produk, Citra Merek dan Minat Beli telah memenuhi syarat uji 
Ni Nyoman Inten Kemara Septiana Putri, Peran Citra Merek...

validitas dimana nilai skor total pada Pearson Correlation masing-masing instrumen berada diatas 0,30 dan memiliki nilai signifikansi yang lebih kecil dari $5 \%(0,05)$, maka instrumen ini layak digunakan menjadi alat ukur variabelvariabel tersebut.

\section{Hasil Uji Reliabilitas}

Pengujian reliabilitas digunakan untuk menguji instrumen penelitian demi untuk mendapatkan hasil bahwa instrumen yang digunakan dapat dipercaya dan diandalkan. Pengujian ini, nilai suatu reablititas ditunjukkan melalui skor Cronbach's Alpha dimana jika nilai skor tersebut berada diatas 0,60 maka instrumen tersebut dapat dikatakan reliabel.

Tabel 4.

\section{Uji Reliabilitas}

\begin{tabular}{rlcc}
\hline No. & \multicolumn{1}{c}{ Variabel } & Cronbach's Alpha & Keterangan \\
\hline 1. & Keunggulan Produk (X) & 0,848 & Reliabel \\
2. & Citra Merek (M) & 0,876 & Reliabel \\
3. & Minat Beli (Y) & 0,921 & Reliabel \\
\hline
\end{tabular}

Sumber: Data primer diolah, 2017

Tabel 4 menunjukkan bahwa hasil dari uji reliabilitas pada masing-masing variabel berada diatas 0,60. Hal ini ditunjukkan dengan hasil dari Crobach Alpha, maka dapat dikatakan bahwa seluruh instrumen yang ada telah memenuhi syarat reliabilitas.

\section{Hasil Uji Normalitas}

Uji normalitas menggunakan uji Kolmogorov-Smirnov, dengan uji ini dapat diketahui data yang digunakan berdistribusi normal atau tidak. Apabila Sign $\mathrm{t}$ 
hitung $>0.05$, maka data tersebut berdistribusi normal dan begitu juga sebaliknya (Santoso, 2001).

Tabel 5.

Hasil Uji Normalitas

\begin{tabular}{|c|c|c|}
\hline & & Unstandardized Residual \\
\hline $\mathrm{N}$ & & 110 \\
\hline \multirow[t]{2}{*}{ Normal Parameters ${ }^{\mathrm{a}, \mathrm{,b}}$} & Mean & .0000000 \\
\hline & Std. Deviation & 2.58149361 \\
\hline \multirow[t]{3}{*}{ Most Extreme Differences } & Absolute & .121 \\
\hline & Positive & .097 \\
\hline & Negative & -.121 \\
\hline Kolmogorov-Smirnov Z & & 1.265 \\
\hline Asymp. Sig. (2-tailed) & & .082 \\
\hline
\end{tabular}

Tabel 5 menunjukkan bahwa nilai signifikansi sebesar $0,082>\alpha=0,05$ maka dapat disimpulkan bahwa data terdistribusi secara normal.

\section{Hasil Uji Multikolinieritas}

Uji multikolinieritas digunakan untuk mengetahui apakah antara variabel bebas terjadi multikolinieritas atau tidak. Uji yang digunakan yaitu dengan melihat nilai VIF (Varian Inflation Factor) dan Tolerance pada proses regresi biasa, jika keduanya mendekati 1 atau besaran VIF kurang dari 10 maka model tidak terkena multikolinieritas.

Tabel 6.

Hasil Uji Multikolinieritas

\begin{tabular}{clcc}
\hline No & \multicolumn{1}{c}{ Variabel } & Nilai Tolerance & Nilai VIF \\
\hline 1. & Keunggulan produk & 0,631 & 1,584 \\
2. & Citra Merek & 0,631 & 1,584 \\
\hline
\end{tabular}

Sumber: Data primer diolah, 2017 
Ni Nyoman Inten Kemara Septiana Putri, Peran Citra Merek...

Hasil uji multikolinearitas pada Tabel 6 menunjukan bahwa nilai tolerance keunggulan produk dan citra merek $>0,1$ dan nilai VIF <10. Jadi dapat disimpulkan bahwa tidak terdapat gejala multikolinearitas.

\section{Hasil Uji Heteroskedasitas}

Uji Heteroskedastisitas bertujuan untuk menguji apakah dalam model terjadi ketidaksamaan varian atau residual satu pengamatan ke pengamatan lainnya. Jika tingkat signifikan lebih besar dari 0,05 maka terjadi heteroskedastisitas.

Tabel 7.

Hasil Uji Heteroskedastisitas

\begin{tabular}{clcc}
\hline No. & \multicolumn{1}{c}{ Variabel } & Sig. & Keterangan \\
\hline 1. & Keunggulan produk & 0,512 & Bebas Heteroskedastisitas \\
2. & Citra merek & 0,193 & Bebas Heteroskedastisitas \\
\hline \multicolumn{2}{l}{ Sumber: } & Data primer diolah, 2017 &
\end{tabular}

Tabel 7 memperlihatkan tingkat signifikansi variabel keunggulan produk dan citra merek > 0,05 sehingga dapat disimpulkan bahwa model terbebas dari gejala heteroskedastisitas.

\section{Hasil Analisis Jalur}

Berdasarkan hasil perhitungan koefisien regresi, nilai error dan determinasi total, maka dapat disusun diagram model analisis jalur seperti pada gambar 2 . sebagai berikut.

Dari diagram jalur tersebut dapat dikalkulasi besaran pengaruh langsung, tidak langsung, serta pengaruh total antar variabel. Kalkulasi pengaruh antar variabel-variabel penelitian dapat diringkas dalam Tabel 8. 


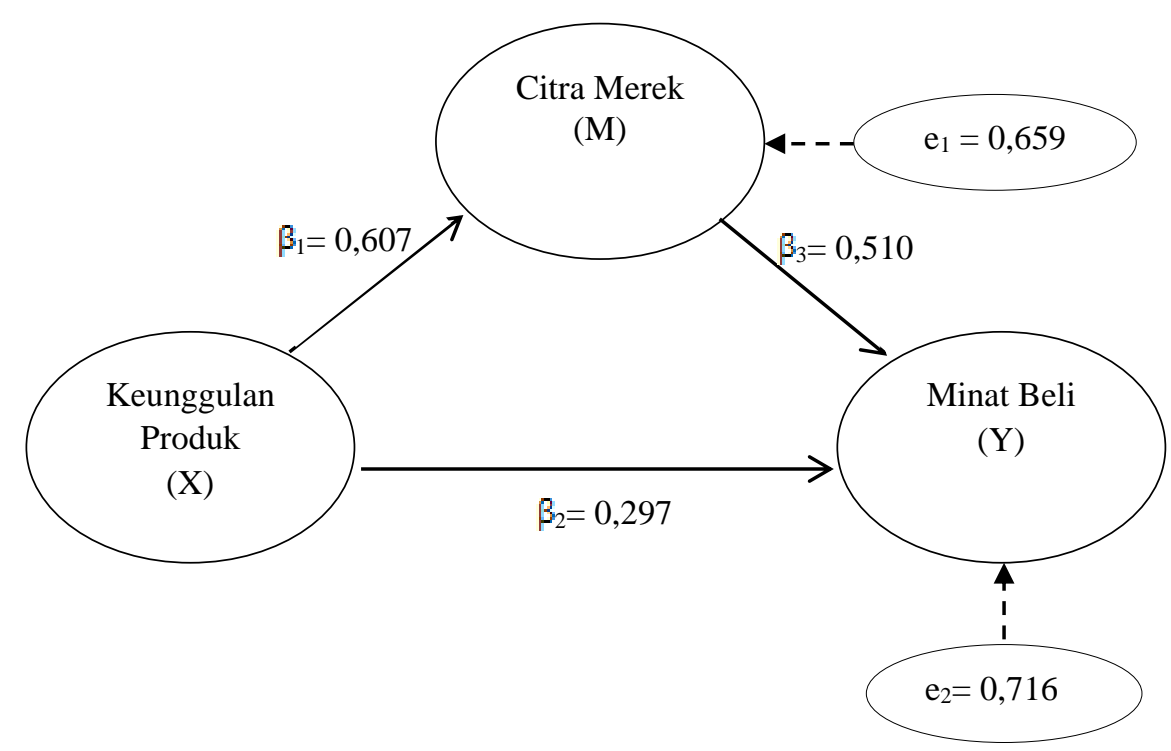

Gambar 2. Diagram Model Analisis Jalur

Sumber: Hasil pengolahan data penelitian, 2017

Tabel 8 menunjukkan keunggulan produk memiliki pengaruh langsung terhadap citra merek sebesar 0,607 dan pengaruh langsung dari keunggulan produk terhadap minat beli sebesar 0,297 sedangkan pengaruh tidak langsung nya sebesar 0,309 sehingga memiliki pengaruh total sebesar 0,309. Citra merek memiliki pengaruh langsung terhadap minat beli sebesar 0,510 .

Tabel 8.

Pengaruh Langsung, Pengaruh Tidak Langsung, dan Pengaruh Total Keunggulan Produk(X), Citra Merek(M) dan Minat Beli(Y)

\begin{tabular}{cccc}
\hline Pengaruh variabel & Pengaruh langsung & $\begin{array}{c}\text { Pengaruh tidak } \\
\text { langsung melalui } \mathbf{X} \\
(\mathbf{M})=\left(\boldsymbol{\beta}_{\mathbf{1}} \times \boldsymbol{\beta}_{\mathbf{3}}\right)\end{array}$ & Pengaruh Total \\
\hline $\mathbf{X} \rightarrow \mathbf{M}$ & 0,607 & - & 0,607 \\
$\mathbf{X} \rightarrow \mathbf{Y}$ & 0,297 & 0,309 & 0,606 \\
$\mathbf{M} \rightarrow \mathbf{Y}$ & 0,510 & - & 0,510 \\
\hline
\end{tabular}

Sumber : Data primer diolah, 2017

Nilai koefisien determinasi total sebesar 0,778 yang berarti bahwa sebesar $77,8 \%$ variabel minat beli dipengaruhi oleh variabel keunggulan produk dan citra 
merek, sedangkan sisanya sebesar $22,2 \%$ dijelaskan oleh faktor lain yang tidak dimasukkan ke dalam model.

\section{Uji Sobel}

Uji sobel digunakan untuk menguji signifikansi variabel citra merek sebagai variabel mediasi dalam hubungan antara variabel keunggulan produk dan minat beli. Uji Sobel yang dilakukan, hasil kalulasi $Z=3,653>1,96$ tingkat signifikansi $0.000<0.05$ berarti variabel mediator citra merek dinilai secara signifikan memediasi pengaruh keunggulan produk terhadap minat beli sepeda motor Yamaha NMax.

\section{Pengaruh keunggulan produk terhadap citra merek}

Hasil pengujian menunjukkan hubungan keunggulan produk terhadap citra merek memperoleh koefisien beta sebesar 0,607 dengan nilai signifikansi sebesar 0,000 atau lebih kecil dari 0,05 , sehingga $\mathrm{H}_{1}$ diterima dan $\mathrm{H}_{0}$ ditolak. Nilai tersebut membuktikan keunggulan produk berpengaruh positif dan signifikan terhadap citra merek. Hasil perhitungan ini memiliki arti, semakin baik Yamaha dalam melakukan keunggulan produk maka akan terjadi peningkatan minat beli begitu pula sebaliknya, saat Yamaha tidak dapat melakukan keunggulan produk dengan baik maka minat beli akan menurun.

Hasil penelitian sebelumnya yang sejalan dengan penelitian ini dikemukakan Keunggulan produk berpengaruh positif terhadap citra merek dapat diterima dan dibuktikan secara statistik dalam penelitian Navarone (2003) dan Krisna (2013). 


\section{Pengaruh keunggulan produk terhadap minat beli}

Hasil pengujian menunjukkan hubungan keunggulan produk terhadap minat beli memperoleh koefisien beta sebesar 0,297 dengan nilai signifikansi sebesar 0,001 atau lebih kecil dari 0,05 , sehingga $\mathrm{H}_{2}$ diterima dan $\mathrm{H}_{0}$ ditolak. Nilai tersebut membuktikan keunggulan produk berpengaruh positif dan signifikan terhadap minat beli. Hasil perhitungan ini memiliki arti, semakin baik Yamaha dalam melakukan keunggulan produk maka akan terjadi peningkatan minat beli begitu pula sebaliknya, saat Yamaha tidak dapat melakukan peningkatan keunggulan produk dengan baik maka minat beli akan menurun.

Hasil penelitian sebelumnya yang sejalan dengan penelitian ini dikemukakan oleh Sylvia (2003) dan Istijanto (2007) menyatakan bahwa keunggulan produk berpengaruh positif dan signifikan terhadap minat beli. Hal serupa juga ditemukan oleh Krisna (2013) dan Tripratiwi,dkk (2016) juga menyatakan bahwa keunggulan produk berpengaruh positif terhadap minat beli.

\section{Pengaruh citra merek terhadap minat beli}

Hubungan citra merek terhadap minat beli memiliki koefisien beta 0,510 dengan signifikansi sebesar 0,000 atau lebih kecil dari 0,05, sehingga $\mathrm{H}_{3}$ diterima dan $\mathrm{H}_{0}$ ditolak. Nilai tersebut memiliki arti bahwa Yamaha semakin memiliki citra merek, minat beliakan semakin meningkat, begitu pula sebaliknya saat Yamaha tidak mampu bersaing maka minat beli menjadi menurun.

Hasil penelitian yang sejalan juga dikemukan Pujadi (2010) dan Arista (2011) menyatakan bahwa terdapat hubungan postif dan signifikan antara citra merek dan minat beli. Hal serupa juga ditemukan oleh Subiyanto (2013) ; Norman 
dan Wang Tsai (2014) dan Tripratiwi,dkk (2016) yang menyatakan citra merek memiliki hubungan positif terhadap minat beli.

\section{Peran citra merek memediasi keunggulan produk dan minat beli}

Hasil pengujian menunjukkan nilai $\mathrm{Z}$ pada uji Sobel sebesar 3,6532 atau lebih besar dari 1,96, sehingga $\mathrm{H}_{4}$ diterima dan $\mathrm{H}_{0}$ ditolak. Hal ini berarti citra merek mampu memediasi secara signifikan pengaruh keunggulan produk terhadap minat beliSepeda motor Yamaha NMax. Semakin baik citra merek yang didasarkan pada keunggulan produk maka peningkatan minat beliakan semakin baik, begitu pula sebaliknya.

Hasil penelitian sebelumnya yang sejalan dengan penelitian ini dikemukakan oleh Alim (2010) dan Norman (2014) menyatakan bahwa adanya pengaruh positif keunggulan produk terhadap minat beli dengan citra merek sebagai variabel mediasi.

\section{Keterbatasan Penelitian}

Keterbatasan dalam penelitian ini adalah ruang lingkup penelitian ini hanya pada minat beli sepeda motor Yamaha NMax di Kelurahan Kuta. Oleh karena itu, hasil penelitian ini tidak dapat digeneralisasikan untuk minat beli sepeda motor Yamaha NMax yang berada di daerah lain. Penelitian ini hanya dilakukan pada satu kurun waktu tertentu saja (cross section), sedangkan lingkungan bersifat sangat dinamis sehingga diharapkan penelitian ini dapat dilakukan kembali di masa mendatang. 


\section{SIMPULAN DAN SARAN}

Keunggulan produk berpengaruh positif dan signifikan terhadap citra merek. Keunggulan produk berpengaruh positif dan signifikan terhadap minat beli. Citra merek berpengaruh positif dan signifikan terhadap minat beli. Citra merek berperan dalam memediasi pengaruh keunggulan produk terhadap minat beli. Berdasarkan hasil dan kesimpulan penelitian, maka ada beberapa saran yang dapat berikan diantaranya diharapkan kedepannya perusahaan dapat terus mengembangkan produk-produk yang dimiliki agar memiliki keunggulan dan dapat menciptakan citra merek bagi produk yang dihasilkan sehingga akan dapat membantu dalam meningkatkan penjualan. Perusahaan diharapkan mampu untuk meningkatkan persepsi dan kepercayaan konsumen terhadap Yamaha NMax sehingga adanya keyakinan bahwa Yamaha NMax memang memiliki perbedaan serta keunggulan yang dapat membedakan produk tersebut dengan pesaingnya. Perusahaan juga diharapkan mampu untuk terus berinovasi mengikuti perkembangan jaman dan meningkatkan ciri khas produk nya agar dapat menonjol dibanding dengan pesaing. Persepsi dan kepercayaan yang sudah terbentuk dengan baik dibenak konsumen tentu akan mampu membantu konsumen dalam memutuskan minat untuk membeli suatu produk atau tidak. Diharapkan kepada penelitian berikutnya untuk meneliti variabel lainnya yang mempunyai pengaruh terhadap minat beli, sehingga mampu menganalisis secara lebih lanjut faktorfaktor yang dapat memengaruhi minat beli. 


\section{DAFTAR RUJUKAN}

Aaker,D.A.1992. Strategic Market Management Third Edition. John Wiley and Sons, Inc.

Adriyani,N. \& Sembriwing,B.K.2012. Analisis strategi merek dan citra merek terhadap keputusan pembelian pada J.co Donuts and Coffee Cabang Cambridge city square meda. Media informasi manajemen.1(2), Pp : 1-12.

Alim,Zaenal.2010.Pelaksanaan Sponsorship Dampaknya terhadap Brand image pada Clothing Linecoltd Sumur Bandung

Andrianto,I.H.N.2013. Pengaruh Kualitas Produk, Citra Merek, Harga dan Promosi Terhadap Keputusan Pembelian Mobil Jenis MPV Merek Toyota Kijang Innova di Semarang. Diponegoro Journal of Management.2(3), Pp $: 1-10$.

Andrew,R. \& Ruslim,S.T.2012. Pengaruh brand image dan product knowledge terhadap purchase intention . Media bisnis.4(1), Pp : 34-44.

Anggar,K.2012. Analisis Pengaruh Harga, Kualitas Produk Dan Promosi Terhadap Keputusan Pembelian Sepeda Motor Honda (Studi Kasus Pada Konsumen di Kota Semarang)

Ambarwati,M.S. \& Kholid,M.M.2015. Pengaruh Citra Merek Terhadap Minat Beli (Survei Pada Mahasiswa Universitas Brawijaya Yang Menggunakan Pasta Gigi Pepsodent). Jurnal Administrasi Bisnis (JAB).25(1), Pp : 1-7.

Arista,E.D. \& Astuti,S.R.T.2011. Analisis Pengaruh Iklan, Kepercayaan Merek, dan Citra Merek terhadap Minat Beli Konsumen. Jurnal Ilmu Ekonomi ASET.13(1), Pp : 37-45.

Arslan,M.2014. Impact of Brand Image and Service Quality on Consumer Purchase Intention: A Study of Retail Store in Pakistan. Research on Humanities and Social Sciences.4(22), Pp : 98-105.

Bagher Javari,S.M. Asef,K. Mehrdad,F. \& Nousha,K.2015. The Effect Of Brand Commitment on e - WOM and Brand Image in the Mobile Market. Research Journal of Applied Sciences. 10(10),Pp : 519-524.

Bian,X \& Moutinho,L.2011.The Role of Brand Image, Product Involvement, And Knowledge In Explaining Consumer Purchase Behavior of Counterfeits Direct And Indirect Effect. European Journal of Marketing.45(1/2). Pp : 191-216. 
Badan Pusat Statistik.2017. Provinsi Bali Dalam Angka 2017. Badung: BPS Bali. Keadaan Geografis Kabupaten Badung.2017.

Djoko,Lesmana Radji.2009. Hubungan Citra Merek, Kepuasan, dan Loyalitas Konsumen. Jurnal Bisnis dan Manajemen.10(1), Pp : 17-34.

Das,Gopal.2014. Linkages of Retailer Awareness, Retailer Association, Retailer Perceived Quality and Retailer Loyalty with Purchase Intention: A Study of Indian Food Retail Brands. Journal of Retailing and Consumer Services.21(3). Pp : 284-292.

Dita, Amanah.2011. Pengaruh Promosi dan Brand Image (Citra Produk) terhadap Loyalitas Pembelian Produk Pepsodent di Ramayana Plaza Jalan Aksara Medan. Jurnal Keuangan dan Bisnis. 3(3). Pp : 221-233.

Elisabeth,A.D 2011. Analisis Pengaruh iklan, Brand Trust, dan Brand image terhadap Minat Beli Konsumen Telkom Speedy di Kota Semarang.Thesis.

Ferdinand.2002. Manajemen Pemasaran. Edisi Pertama. Jilid 1. Jakarta: Salemba Empat.

Fitriana,D. \& Yulianti,I.2014. Pengaruh Brand Image Terhadap Purchase Intention Pada Produk Otomotif (Studi Kasus pada Calon Pembeli Toyota Avansa di Auto 2000 Sutoyo-Malang).2(2)

Ghozali,L.2013. Aplikasi Analisis Multivariate dengan Program IBM SPSS 2.1. Edisi ke 7. Semarang: Badan Penerbit Undip.

Gatignon,Hubert. \& Xuereb,J.M.1997. Strategic Orientation of The Firm And New Product Performance. Journal of Marketing Research.34(1). Pp : 7790 .

Jalivand,Reza Mohammad.2012. The Effect of Electronic Word of Mouth on Brand Image and Purchase Intention. Journal of Marketing Intelligence \& Planning.30(4). Pp : 460-467.

Komaryatin,Nurul. \& Fauziah Fitri Ella.2006. Analisis Pengaruh Keunggulan Produk, Kegunaan Produk Dan Promosi Terhadap Tingkat Kesuksesan Produk Telkom Flexi Di Jepara. Jurnal Dinamika Ekonomi \& Bisnis.3(2). Pp : 155-173.

Kotler,P. \& Keller,K.L.2009. Manajemen Pemasaran. Jilid 1. Edisi ke 13. Diterjemahkan oleh Bob Sabran. Jakarta: Erlangga. 
Khasanah, Imroatul.2011. Pengaruh Atribut Produk, Bauran Promosi, dan Kualitas Pelayanan Terhadap Keputusan Pembelian Produk Merchandise. Jurnal Asset 13(1). Pp : 155-163.

Krisna Hadi, Ryan.2013. Pengaruh Keunggulan Produk Terhadap Minat Beli Konsumen Pada Produk Rangka Atap Baja Ringan Taso C75.75. Jurnal Sains Pemasaran Indonesia.12(3). Pp : 346-356.

Kinnear,Thomas C. \& James R. Taylor.1995. Marketing Research: An Applied Approach. McGraw Hill Text.

Lidya,N.G.W.2016. Analisis Minat Beli Konsumen Dalam Memilih Merek Sepeda Motor.

Lien, Che-Hui. Wen,Miin-Jye. Huang, Li-Ching. \& Wu,Kuo-Lung. The Effect of Brand Image, Price, Trust and Value on Purchase Intentions. Asian Pacific Management Review.20(). Pp : 210-218.

Luong,D.B. Vo,T.H.G. \& Le, K.H.2017. The Impact of Electronic Word of Mouth on Brand Image and Buying Decision: An Empirical Study in Vietnam tourism. International Journal of Research Studies in Management.6(1). Pp : 53-63.

Maryam,T. Tanveer,A. Muhammad,A. \& Asif,I.2017. EWOM and Brand awareness Impact on Consumer Purchase Intention: Mediating role of Brand Image.1(1). Pp : 84-102.

Malhotra,M.K.2012. Operations Management, $10^{\text {th }}$ Edition. USA: Pearson.

Musay,F.P.2013. Pengaruh Brand Image Terhadap Keputusan Pembelian (Survey pada Konsumen KFC Kawi Malang). Jurnal Aministrasi bisnis.3(2). Pp : $1-7$.

Mital,Vikas William.T.R \& Patrick,M.B.1999. Attribute-Level Performance, Satisfaction, and Behavioral Intentions Over Time: A ConsumptionSystem Approach. Journal of Marketing.63(2). Pp : 88-101

Mowen.1995. Perilaku Konsumen dan Komunikasi Pemasaran. Jakarta : karangan Sutisna.

Navarone,Okki.2003. Analisis Pengaruh Tingkat Kesuksesan Produk Baru dalam Peningkatan Minat beli. Jurnal Sains Pemasaran Indonesia.2(1). Pp : 111122. 
Norman,Utami Astri.2014. Hubungan Brand image terhadap Minat Beli pada Distro Rockmen di Kota Bandung.Skripsi Sarjana Manajemen pada Fakultas Bisnis dan Manajemen Universitas Widyatama, Bandung.

Pujadi,Bambang S.E.2010. Studi Tentang Pengaruh Citra Merek Terhadap Minat Beli Melalui Sikap Terhadap Merek (Kasus pada Merek Pasta Gigi Ciptadent di Semarang). Jurnal Sains Pemasaran Indonesia.9(1). Pp : 5976.

Roedjinandari,Nany.2006.Pengaruh faktor perilaku konsumen terhadap keputusan pembelian makanan khas jawa pada rumah makan inggil malang. Jurnal Eksekutif.3(3).

Rahyuda,K., Yasa,G.W.M. \& Yuliarmi,N.2016. Buku Ajar Metodologi Penelitian. Fakultas Ekonomi Universitas Udayana. Denpasar: Fakultas Ekonomi Universitas Udayana.

Rieska,S.R.2013. Pengaruh Brand image terhadap Niat Beli Konsumen pada Distro Dloops di Bandung.

Riduwan \& Kuncoro,E.A.2011. Cara Menggunakan dan Memaknai Analisis Jalur (Path Analylis). Bandung: Alfabeta.

Sugiyono, 2016. Metode Penelitian Bisnis. Bandung: Alfabeta.

Setiawan,I., Anton,A., \& Susila,I.2004. Pengaruh Service Quality Perception Terhadap Purchase Intention: Studi Empirik Pada Konsumen Supermarket. Usahawan, 33(7). Pp : 29-37.

Santoso. 2001. Buku Latihan SPSS Statistik Parametrik.Elex Media Komputindo. Jakarta.

Sutantio,M.2004. Studi Mengenai Pengembangan Minat Beli Merek Ekstensi; Studi Kasus Produk Sharp di Surabaya. Jurnal Sains Pemasaran Indonesia. 3().

Suparta,I.G. \& Sujaya,I.M.2010. Kuta Kita: Catatan Kecil Kuta Membangun,Cetakan Pertama. Kuta: Pemerintah Kelurahan Kuta.

Surya Ningrum,Lily \& Nurcahya, I Ketut.2014. Pengaruh Pelaksanaan Program Corporate Social Responsibility (CSR) Terhadap Corporate Image dan Perilaku Word-of-Mounth (WOM) pada PT.Sidomuncul. E-Jurnal Manajemen Universitas Udayana.3(3). Pp : 2302-8912. 
Song,Michael \& Parry,Mark E.1997. A Cross National Comparative Study of New Product Development Proses: Japan and the US. Journal of Marketing.

Simbolon,Y.2013. Pengaruh Diferensiasi Produk dan Minat Beli Konsumen Terhadap Keputusan Pembelian Sepeda Motor Yamaha Mio Automatic pada Mahasiswa Fakultas Ekonomi UNIMED.

Tripratiwi,D. Minarsih,M \& Hasiolan,L.B.2016. Analisis Pengaruh Harga, Keunggulan Produk Dan Citra Merek Terhadap Minat Konsumen Dalam Pembelian Mobil Mitsubishi Sport Pada PT Bumen Redja Abadi Semarang. Journal of Management.2(2).

Teresa,T.H. Kuen-Hung,T \& Yi-Chuan, L.2013. How Product Advantage Mediates the Product Innovativeness-New Product Performance Relationship: The Moderating Role of Environmental Context. Online Academic Journal of Information Technology.24(15).Pp : 1-15.

Torlak,O. Behcet,Y.O. Muhammet,A.T. \& Mehmet, F.D.2014. The Effect of Electronic Word of Mouth on Brand Image and Purchase Intention: An Application Concerning Cell Phone Brands for Youth Consumers in Turkey. Journal of Marketing Development and Competitiveness. 8(2). Pp : 61-68.

Voss,G.B. \& Zannie,G.V.2000. Strategic Orientation and Firm Performance in an Artistic Enviroment. Journal of Marketing.64(). Pp : 68.

Utama,S.M.2009. Aplikasi Analisis Kuantitatif (Edisi Ketiga). Denpasar. Sastra Utama.

Urban Glen L. \& Hauser John R., 1998, Desight and Marketing of New Products, Prentice Hall Inc

Wang,Hui-Ya. \& Tsai,Chi-Fen.2014. The Relationship between Brand image and Purchase Intention : Evidence From Award Winning Mutual Funds.The International Journal of Business and Finance Research.8(2),Pp : 27-40.

Woran,N. Tumbel,A. \& Rate,P.V.2016. Pengaruh Costumer Relationship Marketing, Nilai, Keunggulan Produk Dan Kepuasan Terhadap Loyalitas Nasabah (Studi Pada Bank Mega Jl. Piere Tendean Mega Mall Manado). Jurnal Berkala Ilmiah Efisiensi.16(1).

www.yamaha.com PT. Yamaha Motor. Diunduh pada Rabu, 05 Juli 2017.

www.semisena.com Fitur Tambahan pada Yamaha NMax. Diunduh pada Jumat, 01 September 2017. 
E-Jurnal Manajemen Unud, Vol. 7, No. 10, 2018: 5539-5569

www.motoengine.com Penjualan Sepeda Motor Yamaha.2016. Diunduh pada Selasa, 05 Desember 2017.

www.motorbloginfo.wordpress.com Grafik Penjualan dan Rata-rata per bulan.2017. Diunduh pada Rabu, 29 November 2017. 